\title{
Clinical value of screening serum squamous cell carcinoma antigen (SCCA) for $\mathrm{HCC}$
}

\author{
Mohamed A.Ezzel Arab ${ }^{1}$, Mohammad A.Hassanein ${ }^{2}$, Nashwa A. Abd El \\ Moniem ${ }^{3}$,Mohamed Hassany ${ }^{2}$,Salah Eldeen M. Ahmad ${ }^{2}$, Amin M. Abd El Baki ${ }^{2}$. \\ ${ }^{1}$ Internal Medicine Department, ${ }^{2}$ Tropical Medicine Department,${ }^{3}$ Clinical Pathology \\ Department -National Hepatology And Tropical Medicine Research \\ Institute,Cairo,Egypt
}

\begin{abstract}
Background: Hepatocellular carcinoma (HCC) is the fifth most common malignancy in the world. In Egypt, HCC was reported to account for about $4.7 \%$ of chronic liver disease (CLD) patients. Squamous cell carcinoma antigen (SCCA) has been reported to be strongly expressed in $\mathrm{HCC}$ tissue hampering its extensive use in clinical practice.
\end{abstract}

Aim: Study the value of serum squamous cell carcinoma antigen (SCCA) for screening of HCC.

Materials \& Method: The study comprised of two groups. Group A included 60 patients with HCC diagnostically confirmed by spiral CT, elevated alfa-fetoprotein (AFP), and/or liver biopsy .Group B CLD patients diagnosed on clinical, laboratory, and ultrasonographical investigations; group B suclassified into three categories according to CHILD-PUGH score included 30 patients, matched for sex and age. All groups were subjected to thorough history taking, full clinical examination, and laboratory investigations including liver functions, viral markers, and AFP and SCCA estimation using ELISA technique.

Results: This study revealed a highly significant difference between patients with HCC and CLD regarding serum SCCA levels being higher in group $\mathrm{A}(10.35 \pm 20.677)$ than group $B(1.64 \pm 2.462)(p=0.02)$. SCCA level was elevated in patients with HCC with normal AFP levels representing its useful role in early detection and follow-up of patients treated for HCC. The cut-off value was established at $2 \mathrm{ng} / \mathrm{ml}$ with sensitivity of $80 \%$ and specificity of $70 \%$ ).

Conclusion: SCCA could represent a useful tool as a marker for detection of HCC.

Key words: Hepatocellular carcinoma, squamous cell carcinoma antigen, tumor markers

\section{Introduction}

Hepatocellular carcinoma (HCC) is the fifth most common cancer in the world. Because of its increased incidence in the last decade and the estimated further increase in the next 2 decades, HCC is arousing great interest (Giannelli et al, 2005).

Hepatocellular carcinoma (HCC) is one of the most important sanitary problems over the world for its high prevalence and for its poor prognosis. More than 250.000 new cases per year are diagnosed and mean 5year survival is lower than $5 \%$ (Pontisso et $a l, 2004) . \mathrm{HCC}$ as it is a highly malignant tumor with a very poor prognosis so early detection and treatment are required (Nomura et al, 1993).

In Europe and North America, it commonly develops on cirrhotic livers, and surveillance programs have therefore been suggested to identify early $\mathrm{HCC}$, at a stage when it remains suitable for surgical therapy and has a better clinical outcome (Giannelli et al, 2005). 
Egypt, like the Western countries has an overall frequency of $\mathrm{HCC}$ of $2.3 \%$ among other types of cancer (El Bokainy, 1998).

There is apparent increase in the number of HCC patients attending the various oncology centers in Egypt and all over the world(Shamaa et al,1992). The annual report of cancer registry of metropolitan Cairo area (1976-1980) had shown rising incidence of primary hepatic malignancies from $1.5 \%$ to $2 \%$ of total cancers $(\boldsymbol{E l}$ Zayadi,1989). In 2001, HCC in Egypt was reported to account for about $4.7 \%$ of chronic liver disease (CLD) patients(El Zayadi et al,2001).. In another study on 2005 , a remarkable increase from $4 \%$ to $7.2 \%$ was reported over a decade(El Zayadi et al,2005).

Ramsey and Wu-Gy (1995) stated that AFP level and abdominal ultrasonography remain the cornerstones of screening for HCC.

AASLD practice guideline, 2005 recommended that surveillance for HCC should be performed using ultrasonography and AFP for screening at 6 to12 month intervals.

Alpha-fetoprotein (AFP), the only marker commonly used in clinical practice, displays poor sensitivity and a high specificity only for values higher than 400 IU/ml. However, because AFP concentrations are directly correlated with tumor size, the reliability of such a marker appears inadequate for early recognition of HCC (Farinati F et al,2006). This has prompted a high number of studies conducted to validate different new biomarkers, but very little has yet been reported about biomarkers helping to achieve an early detection of HCC (Giannelli et al, 2006). All the proposed biomarkers failed to discriminate between liver cirrhosis (LC) and HCC in a satisfactory manner, in terms of diagnostic accuracy, reproducibility of the results, or technical issues related to the biomarker detection method ( Marrero JA, Lok $A S, 2004)$. For this reason, the simultaneous use of different tests seems to offer a promising approach that warrants further investigation (Giannelli et al, 2007). It has been reported that the squamous cell carcinoma antigen (SCCA) is over expressed in HCC patients both in tissue (Giannelli et al, 2005), and in serum (Moubarak,et al 2008).

Squamous cellular carcinoma antigen (SCCA), is a member of the high molecular weight family of serine protease inhibitors named serpins (Suminami et al, 1991). Two highly homologous isoforms have been reported to be expressed in HCC tissues at protein and translational levels (Pontisso et $a l, 2004)$.SCCA has also been reported to be overexpressed in tumoral compared to paired peritumoral tissue of $\mathrm{HCC}$, suggesting a role as a potential marker for histological detection of HCC (Giannelli et al, 2005). Recently, SCCA has been investigated in regenerative and dysplastic nodules of HCC tissue. Interestingly, results show that SCCA was poorly expressed in regenerative tissue but strongly increased in dysplastic nodules, suggesting a role as a potential marker for early detection of $\mathrm{HCC}$ (Guido et al, 2008). these results were strengthed by (Trerotoli et al,2009) which mentioned that (SCCA) is inversely correlated to tumor size.

SCCA variants are over expressed in HCC, independently of tumor etiology. A novel SCCA1 variant has been identified in one third of liver tumors. .The serpin squamous cell carcinoma antigen (SCCA) is over expressed in liver cancer and circulating SCCA-IgM complexes have been described in patients with hepatocellular carcinoma (HCC) (Pontisso et al, 2006).

Giannelli et al (2005) concluded that the combined use of AFP and SCCA antigen represents a more powerful tool for the serologic detection of HCC.

\section{Materials and Methods}

This study was conducted for one year on 90 patients with chronic liver disease admitted to Hepatology and Gastroenterology Department, or attending 
for the screening clinic for HCC, NHTMRI, during May 2006 to April 2007 were evaluated. Apart from obtaining a detailed clinical history, general and abdominal examinations were done for all the selected patients. The patients underwent laboratory investigations that included complete blood picture, ESR ,renal function tests(s. creatinine,bl.urea), liver function tests (ALT,AST,s.bilirubin T\&D,s albumin,s A $\mathrm{Ph}$,Proth. time\&conc), serological tests for viral markers (HBsAg,HCV Ab), AFP and squamous cell carcinoma antigen (SCCA). Determination of the previous biochemical tests was done using ELISA technique.

Abdominal ultrasonography was done to determine the liver size, echogenicity, presence of focal lesions (size, number, and echogenicity), portal vein (patency, diameter) and presence of ascites. Spiral triphasic abdominal CT scan was used to confirm the findings of abdominal ultrasonography and for studying of suggestive criteria for HCC (early enhancement in arterial phase, rapid washout in subsequent phases -

portovenous and delayed phases). If needed, liver biopsy and histopathological examination were done for patients with hepatic focal lesion detected by the ultrasound and missing the $\mathrm{HCC}$ criteria in spiral CT or with normal AFP, then the selected patients were set into two groups:

1-Group A: consisting of 60 patients with HCC confirmed by spiral

triphasic CT scan, elevated AFP levels > 200, and/or liver biopsy

2- Group B: consisting of 30 patients with chronic liver disease subclassified into 3 groups:

- Group I: consisting of 10 patients with child "A" cirrhosis.

- Group II: consisting of 10 patients with child "B" cirrhosis.

- Group II: consisting of 10 patients with child " $\mathrm{C}$ " cirrhosis.

And according to manufacturering we consider "SCCA" test to be positive at cut off level of $(2.0 \mathrm{ng} / \mathrm{ml})$.

AFP has significant positive elevation at cut off level of $(200 \mathrm{ng} / \mathrm{ml})$.
Exclusion criteria included patients with squamous cell carcinoma other than HCC, Patients with acute liver disease and patients with abnormal renal functions.

\section{Statistical Methods}

Analysis of the data was done using statistical program for social science (SPSS). The quantitative variables are described in the form of mean and standard deviation, while the qualitative variables are described in the

form of frequency and percentages. Chi square test (X2 value) was used to compare a qualitative variable between two independent groups. Spearman correlation test (rho value) was used to rank different nonparametric variables against each other, either positively or inversely.Pearson correlation was used to rank different parametric variables against each other, either positively or inversely

$P$ value (which is either non-significant (NS) if $>0.05$, significant (S) if $<0.05$, or highly significant (HS) if $<0.02$ ) was calculated.

The diagnostic accuracy of AFP and SCCA were determined by receiver operator characteristic (ROC) curve analysis, reporting AUC and its $95 \%$ confidence interval. The diagnostic cut off and the related sensitivity and specificity were determined.

Sensitivity (ability of the test to detect positive cases) $=$ true positive/ (true positive + false negative).

Specificity (ability of the test to exclude negative cases) $=$ true negative/(true negative + false positive).

Positive predictive value $(\mathrm{PPV})=$ percent of the true positive to all positive cases.

Negative predictive value $(\mathrm{NPV})=$ percent of the true negative to all negative cases.

\section{Results}

The demographic data of the studied groups are illustrated in table (1),(2), Fig(1)., describing that there were 25 males $(83 \%)$ and $5(17 \%)$ females among patients with CLD, this male predominance was also observed in patients with HCC (48 patients representing $80 \%$ ), Mean while no 
significant difference between the studied groups as regarding age, the urban nature in patients of both studied groups was clearly observed ,that is may contributed to the presence of $\mathrm{HCC}$ screening programs in the tertiary centers of treatment in urban areas.

Table 1: Demographic data of the studied groups.

\begin{tabular}{|c|c|c|c|c|c|c|c|}
\hline & ariable & Gro & & $\begin{array}{l}\text { Gro } \\
\text { ( }\end{array}$ & $\begin{array}{l}\text { "B" } \\
0)\end{array}$ & $\mathrm{P}$ value & Sig \\
\hline & & Mean & SD & Mean & SD & & \\
\hline & ge (yrs) & 56.33 & 9.438 & 49.90 & 12.729 & 0.018 & NS \\
\hline & Male & & & & & 0.703 & NS \\
\hline $\bar{n}$ & Female & & & & & & \\
\hline & Total & & & & & & \\
\hline
\end{tabular}

The demographic distribution of the studied groups is shown in table (2),Fig(1).

Table 2: Demographic distribution of the studied groups.

\begin{tabular}{|l|l|l|}
\hline \multirow{2}{*}{ Residence } & \multicolumn{2}{|c|}{ Groups } \\
\cline { 2 - 3 } & Group A & Group B \\
\hline Urban & 34 & 22 \\
\hline Rural & 26 & 8 \\
\hline Total & 60 & 30 \\
\hline
\end{tabular}


Clinical value of ....

Fig(1): Demographic distribution of the studied groups.

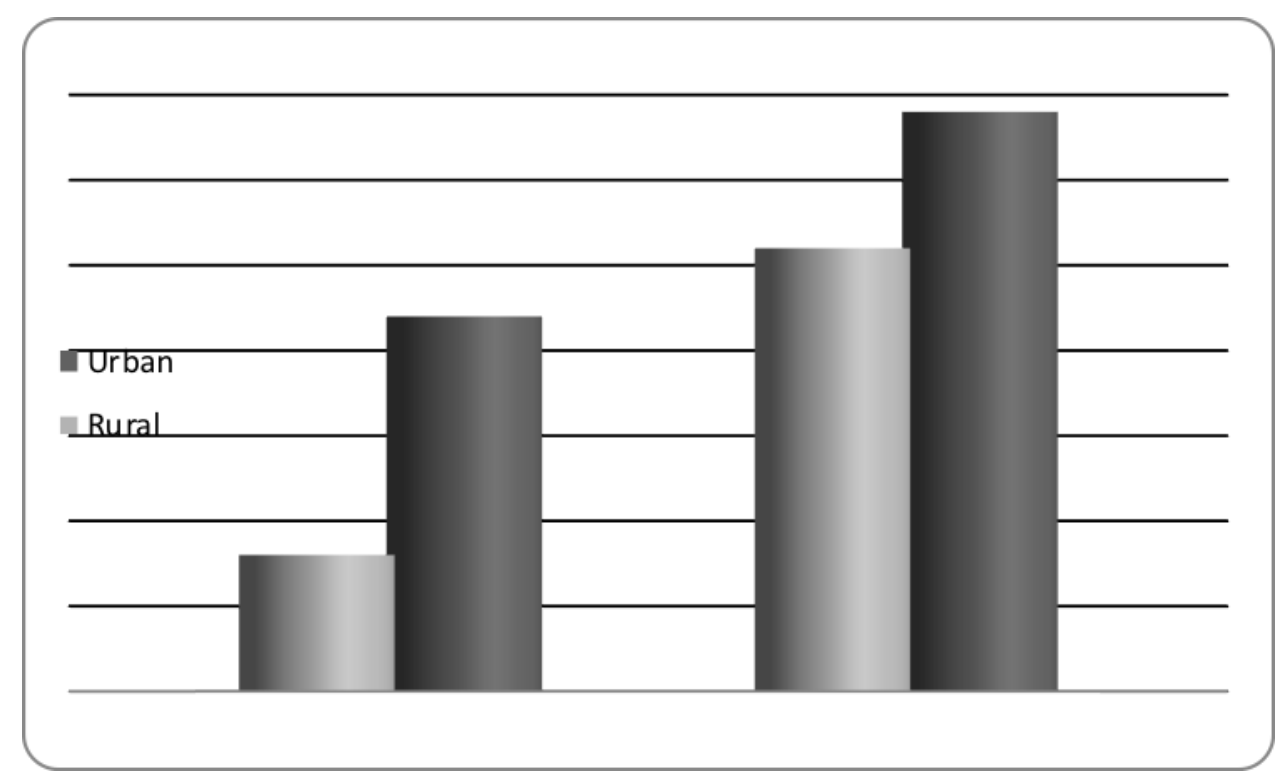

Table (3) shows statistical comparison between the HCC group of patients (group A) and the CLD patients(group B) as regarding AST,ALT,Bil,Albumin,AFP \&SCCA. High Significant difference was observed between both studied groups as regarding SCCA levels being higher in group $\mathrm{A}(10.35 \pm 20.677)$ than group $\mathrm{B}(1.64 \pm 2.462)(\mathrm{p}=0.02)$ mean while ,no significant difference in AFP levels being(1405.244 \pm 7716.0248$)$ in group A and (31.523 \pm 61.9688$)$ in group B ( $>0.05)$.

Table 3: Laboratory data of the studied groups.

\begin{tabular}{|c|c|c|c|c|c|c|}
\hline \multirow[t]{2}{*}{ Variable } & \multicolumn{2}{|c|}{$\begin{array}{c}\text { Group "A" } \\
(\mathrm{N}=60)\end{array}$} & \multicolumn{2}{|c|}{$\begin{array}{c}\text { Group"B" } \\
(\mathrm{N}=30)\end{array}$} & \multirow[t]{2}{*}{$\mathrm{P}$ value } & \multirow[t]{2}{*}{ Sig } \\
\hline & Mean & $\mathrm{SD}$ & Mean & SD & & \\
\hline AST & 68.82 & 33.734 & 56.37 & 42.861 & .171 & NS \\
\hline ALT & 49.95 & 22.959 & 95.17 & 87.640 & .000 & $S$ \\
\hline Bilirubin & 1.569 & .5722 & 6.125 & 9.1078 & .000 & $S$ \\
\hline Albumin & 3.143 & .5416 & 2.970 & 1.0269 & .296 & NS \\
\hline AFP & 1405.244 & 7716.0248 & 31.523 & 61.9688 & .173 & NS \\
\hline SCCA & 10.35 & 20.677 & 1.64 & 2.462 & .002 & $S$ \\
\hline
\end{tabular}

HCV infection was predominant in both studied groups as shown in table (4) 
Table 4: Viral status of the studied groups.

\begin{tabular}{|c|c|c|}
\hline Variable & $\begin{array}{c}\text { Group "A" } \\
(\mathrm{N}=60)\end{array}$ & $\begin{array}{c}\text { Group"B" } \\
(\mathrm{N}=30)\end{array}$ \\
\hline HBV & 3 & 1 \\
\hline HCV & 57 & 28 \\
\hline COMBINED & 0 & 1 \\
\hline
\end{tabular}

Table 5: Statistical difference of AFP levels between the studied groups.

\begin{tabular}{|c|c|c|c|c|}
\hline \multirow{3}{*}{ Variable } & Group & VS & $\begin{array}{c}\text { Mean } \\
\text { Difference }\end{array}$ & Sig. \\
\hline \multirow{4}{*}{ AFP } & A & B1 & 1402.0542 & 1.000 \\
\cline { 2 - 5 } & & B2 & 1379.2542 & 1.000 \\
\cline { 2 - 5 } & & B3 & 1339.8542 & 1.000 \\
\cline { 2 - 5 } & B1 & A & -1402.0542 & 1.000 \\
\cline { 2 - 5 } & & B2 & -22.8000 & 1.000 \\
\cline { 2 - 5 } & & B3 & -62.2000 & 1.000 \\
\cline { 2 - 5 } & & B 2 & -1379.2542 & 1.000 \\
\cline { 2 - 5 } & & B1 & 22.8000 & 1.000 \\
\cline { 2 - 5 } & & B3 & -39.4000 & 1.000 \\
\cline { 2 - 5 } & & A & -1339.8542 & 1.000 \\
\cline { 2 - 5 } & & B1 & 62.2000 & 1.000 \\
\hline
\end{tabular}

Table (6) showed that SCCA test had no significant difference between group "A" versus the three subcategories of the group "B", the test was positive in 48 patients of group "A",8 patients of group "B-1" and only 1 patient in groups "B-2","B-3" .

Table 6: Statistical difference of SCCA levels between the studied groups.

\begin{tabular}{|c|c|c|c|c|}
\hline \multirow{3}{*}{ Variable } & Group & VS & Mean & Sig. \\
& & & Difference & \\
\hline \multirow{4}{*}{ SCCA } & A & B1 & 7.060 & 1.000 \\
\cline { 2 - 5 } & & B2 & 9.550 & .643 \\
\cline { 2 - 5 } & & B3 & 9.520 & .649 \\
\cline { 2 - 5 } & B1 & A & -7.060 & 1.000 \\
\cline { 2 - 5 } & & B2 & 2.490 & 1.000 \\
\cline { 2 - 5 } & & B3 & 2.460 & 1.000 \\
\cline { 2 - 5 } & B2 & A & -9.550 & .643 \\
\cline { 2 - 5 } & & B1 & -2.490 & 1.000 \\
\cline { 2 - 5 } & & B3 & -.030 & 1.000 \\
\cline { 2 - 5 } & & A & -9.520 & .649 \\
\cline { 2 - 5 } & & B1 & -2.460 & 1.000 \\
\hline
\end{tabular}


Table 7: Sensitivity, specificity, positive predictive value, and negative predictive value of alpha fetoprotein and SCCA at various cut-off values.

\begin{tabular}{|c|c|c|c|c|c|}
\hline \multirow{3}{*}{} & $\begin{array}{c}\text { Cut-off } \\
\text { values } \\
\mathrm{ng} / \mathrm{ml}\end{array}$ & Sensitivity & Specificity & PPV & NPV \\
\hline \multirow{3}{*}{ AFP } & 10 & $80 \%$ & $66.67 \%$ & $82.76 \%$ & $62.5 \%$ \\
\cline { 2 - 6 } & 200 & $36.67 \%$ & $100 \%$ & $100 \%$ & $44.12 \%$ \\
\cline { 2 - 6 } & 400 & $23.33 \%$ & $100 \%$ & $100 \%$ & $39.47 \%$ \\
\hline \multirow{3}{*}{ SCCA } & 0.5 & $100 \%$ & $23.33 \%$ & $72.29 \%$ & $100 \%$ \\
\cline { 2 - 6 } & 1 & $100 \%$ & $50 \%$ & $80 \%$ & $100 \%$ \\
\cline { 2 - 6 } & 2 & $80 \%$ & $70 \%$ & $84.21 \%$ & $63.64 \%$ \\
\hline
\end{tabular}

\section{ROC Curve}

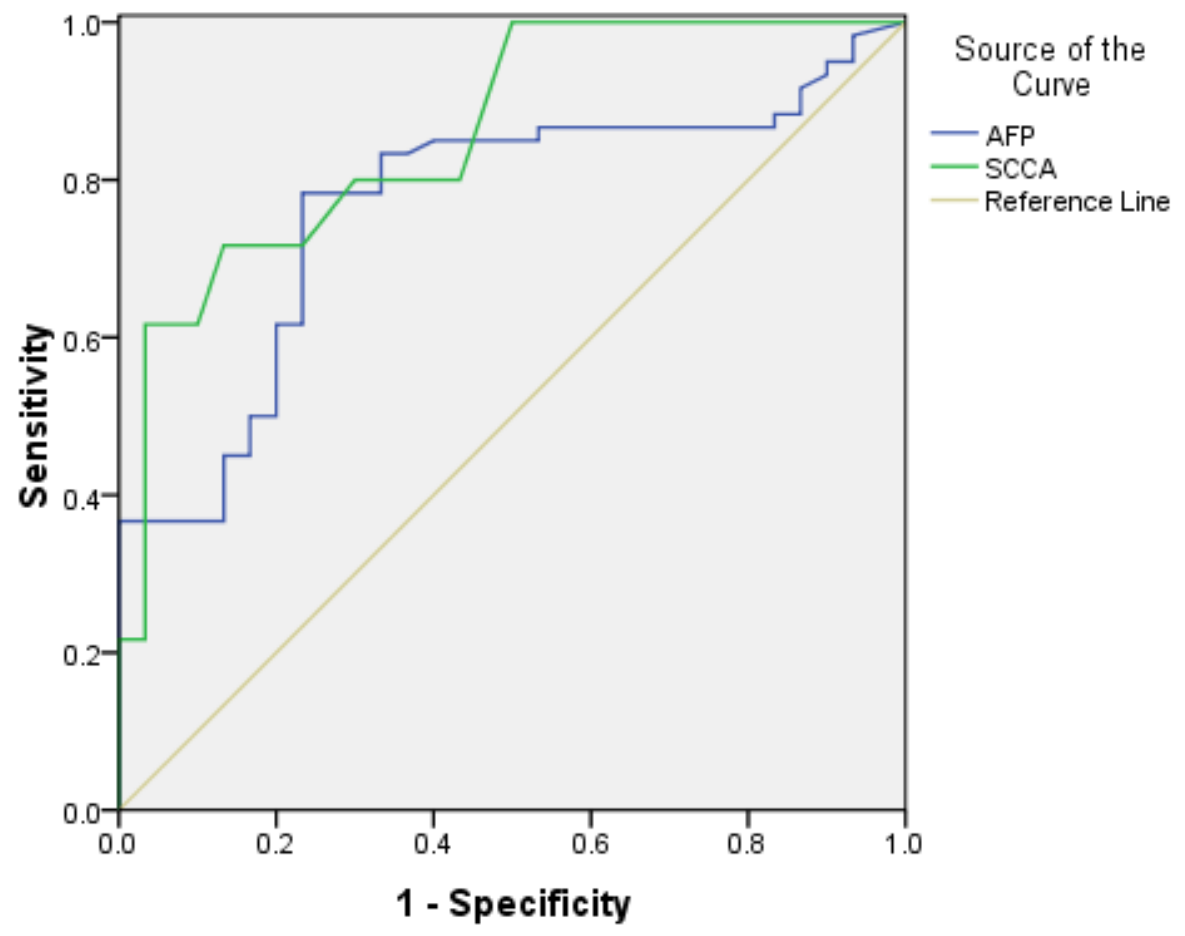

Fig 2: ROC curve showing specificity and sensitivity of AFP and SCCA

As shown in Table(7), Fig(2), the area under the curve (AUC) of SCCA was 0.859 (95\% CI $0.780-0.939)$, the cut off value was established at $2 \mathrm{ng} / \mathrm{ml}$ with sensitivity of $80 \% \%$ and specificity of $70 \%$. (AUC) of AFP was 0.767 (95\% CI $0.665-0.868$ ), the significant cut off value was established at $200 \mathrm{ng} / \mathrm{ml}$ with sensitivity of $36.67 \% \%$ and specificity of $100 \%$.

High Significant correlation was found between AFP and SCCA level in both studied groups $(\mathbf{P}<0.02)$,also AFP showed high significant correlations with the total tumor size measured by CT,this correlation was not achieved as regarding SCCA level in those patients. 


\section{Discussion}

Detection of HCC at an early stage may reduce mortality significantly. This particular malignancy develops in $90 \%$ of patients who are affected by cirrhosis or chronic hepatitis, and mass screening may be justified, because 1) the at-risk population can be identified easily, 2) tumor ablation or resection at an early stage can increase survival, and 3) HCC tends to grow slowly and to stay confined to the liver. However,massive screening should be justified only when sensitive and specific diagnostic procedures are available.Currently, US and AFP monitoring are the only reasonable screening strategy to detect $\mathrm{HCC}$, but they are not effective enough to justify massive screening programs (Trevisani et al,2001). SCCA is a serine protease inhibitor that is found physiologically in the spinous and granular layers of normal squamous epithelium, but it is expressed typically by neoplastic cells of epithelial origin, and it has been used as serologic marker of cervical squamous cell carcinoma (Gadducci et al, 2004) Therefore, SCCA overexpression also may characterize other types of epithelial tumors.

In our study SCCA was expressed in most HCC cases and to lesser extent in the control group, these results seem encouraging, although the partial overlap of the SCCA reference limits affects the ability to detect HCC among cirrhotic patients. This could be explained by the relatively low specificity of the SCCA antigen. Nevertheless, because of its high sensitivity, the diagnostic discrimination between HCC and liver cirrhosis is improved in those cases where AFP is not elevated ,these goes with the results of(Giannelli et al, 2005)(Beneduce et al,2004) . Regarding the false positives among the cirrhotic patients, it is also possible that the altered immune response commonly observed in cirrhotic patients may affect the specificity of the ELISA kit used for SCCA detection.

Also AFP shows stepladder elevation between the studied groups being least level in the CHILD A group then B then and finally it reaches the highest level in the HCC group, and it shows great correlation to the tumor size, and this may agrees with some of the published studies which elevate the role of AFP in early prediction of HCC and its correlation with the tumor size especially if it's combined with other markers like GPC3, PIVKAII and SCCA) like (Beale et al, 2008).

$\mathrm{HCC}$ is a major rising problem worldwide, detection of simple markers for early detection of HCC and screening of at risk patients is a great goal aiming to be achieved. The results of our study suggest that SCCA could represent a useful tool as a marker for detection of HCC and for differential diagnosis between HCC and cirrhosis ,utilizing SCCA together with AFP may raise the possibility for early detection of HCC .

\section{Summary:}

The results of our study suggest that SCCA could represent a useful tool as a marker for detection of HCC and for differential diagnosis between $\mathrm{HCC}$ and cirrhosis as we found that the levels of SCCA are significantly higher in patients with $\mathrm{HCC}$ than in CLD patients and controls.

\section{Recommendation:}

More studies on a large scale are needed to assess the diagnostic as well as the prognostic value of SCCA in patients with HCC with different

etiologies of liver disease. Further studies focusing on the quantitative assessment of SCCA in tumor and peritumoral tissues should be utilized. Also,multivariate analytical studies are needed to evaluate various clinical, laboratory, and radiological parameters to improve the diagnostic accuracy for early detection of HCC.

\section{References}

- $\quad$ Beale G, Chattopadhyay D, Gray J, Stewart S, Hudson M, Day C, Trerotoli P, Giannelli G, Manas D, Reeves H. AFP, PIVKAII, GP3, SCCA-1 and follisatin as surveillance biomarkers for hepatocellular cancer in non-alcoholic and alcoholic fatty liver disease. BMC Cancer. 2008 Jul 18;8:200. 
- Beneduce L, Castaldi F, Marino M, Tono N, Gatta A, Pontisso P, Fassina G. Improvement of liver cancer detection with simultaneous assessment of circulating levels of free alpha-fetoprotein (AFP) and AFP-IgM complexes. Int J Biol Markers. 2004 AprJun;19(2):155-9.

- Bruix J, Sherman M; Practice Guidelines Committee, American Association for the Study of Liver Diseases. Management of hepatocellular carcinoma.Hepatology. 2005 Nov;42(5):1208-36.

- El Bokainy NM. Epidemiology of cancer. In: El Bokainy NM,.General pathology: Al-Asdekaa Graphics Center; (1998). p. 77.

- El Zayadi AR. Primary hepatic malignancies, highlighting the Egyptian situation. Med Pharmacol (1989);33:202-7.

- El Zayadi AR, Abaza H, Shawky S, et al. Prevalence and epidemiological features of hepatocellular carcinoma in Egypt, a single center experience. Hepatol Res (2001);19(2):170-9.

- El Zayadi AR, Badran HM, Barakat EM, et al. Hepatocellular carcinoma in Egypt: A single center study over a decade. World J Gastroenterol (2005);11(33):5193-8.

- Farinati F, Marino D, DE Giorgio M, Baldan A, Cantarini M, Cursaro C, Rapaccini G, Del Poggio P, Di Nolfo MA, Benvegnu L, Zoli M, Borzio - F, Bernardi M, Trevisani F: Diagnostic and prognostic role of alpha-fetoprotein

in hepatocellular carcinoma:both or neither?Am $\mathrm{J}$ Gastroenterol 2006:524-532.

- Gadducci A, Cosio S, Gargini A, Genazzani AR. Sex-steroid hormones, gonadotropin and ovarian carcinogenesis: a review of epidemiological and experimental data. Gynecol Endocrinol. 2004 Oct;19(4):216-28.

- Giannelli G, Marinosci F, Trerotoli P, Volpe A, Quaranta M, Dentico P, Antonaci S. ,SCCA antigen combined with alpha-fetoprotein as serologic markers of HCC.Int J Cancer. 2005 Nov 10;117(3):506-9.

- Giannelli G, Marinosci F, Sgarra C, Lupo L, Dentico P, Antonaci S. Clinical role of tissue and serum levels of SCCA antigen in hepatocellular carcinoma.Int J Cancer. 2005 Sep 10;116(4):579-83.

- Giannelli G, Antonaci S: New frontiers in biomarkers for hepatocellular carcinoma. Dig Liver Dis 2006:854-859.

- Giannelli G, Fransvea E, Trerotoli P, Beaugrand M, Marinosci F, Lupo

L, Nkontchou G, Dentico P, Antonaci S: Clinical validation of combined serological biomarkers for improved hepatocellular carcinoma diagnosis in 961 patients. Clin Chim Acta 2007:147-152.
- Guido M, Roskams T, Pontisso P, Fassan M, Thung SN, Giacomelli L,Sergio A, Farinati F, Cillo U, Rugge M: Squamous cell carcinoma antigen in human liver carcinogenesis. J Clin Pathol 2008,61(4):445-7.

- Marrero JA, Lok AS: Newer markers for hepatocellular carcinoma. Gastroenterology 2004:S113-S119.

- Moubarak M.Hussein, Amany A. Ibrahim, Heba M.Abdella1, Iman F.Montasser and M. Ismail Hassan. Serum Squamous Cell Carcinoma Antigen as a new marker for Hepatocellular Carcinoma: a Preliminary Study The Afro-Arab Liver Journal,2008 Vol. 8, No. 1:1-8.

- Nomura Y,Matsuda Y,Yabuuchi I,Nishioka M,Tarui S.Hepatocellular carcinoma in adenomatous hyperplasia :detection with contrast-enhanced US with carbon dioxide microbubbles .Radiology.1993 May;187(2):353-6.

-Paolo Trerotoli, Emilia Fransvea, Umberto Angelotti, Giovanni Antonaci2, Luigi Lupo, Antonio Mazzocca, Anita Mangia,Salvatore Antonaci and Gianluigi Giannelli. Tissue expression of Squamous Cellular Carcinoma Antigen (SCCA) is inversely correlated to tumor size in HCC. Molecular Cancer 2009, 8:29

-Pontisso $\mathrm{P}$, Calabrese $\mathrm{F}$, Benvegnù $\mathrm{L}$, Lise $\mathrm{M}$, Belluco C, Ruvoletto MG, Marino M, Valente M, Nitti D, Gatta A, Fassina G., Overexpression of squamous cell carcinoma antigen variants in hepatocellular carcinoma.Br J Cancer. 2004 Feb 23;90(4):833-7.

-Pontisso P, Quarta S, Caberlotto C, Beneduce L, Marino M, Bernardinello E, Tono N, Fassina G, Cavalletto L, Gatta A, Chemello L.Progressive increase of SCCA-IgM immune complexes in cirrhotic patients is associated with development of hepatocellular carcinoma. Int J Cancer. 2006 Aug 15;119(4):735-40.

- Ramsey WH, Wu GY. Hepatocellular carcinoma: update on diagnosis and treatment. Dig 1995 MarApr;13(2):81-91.

-Shamaa S, El Bedawy AF, Azzam F, et al. Hepatocellular carcinoma in Egypt: Analysis of 192 cases. J Egypt Nat Cancer Inst (1992);5(4):761-72.

-Suminami Y, Kishi F, Sekiguchi K, Kato H: Squamous cell carcinoma antigen is a new member of the serine protease inhibitors. Biochem Biophys Res Commun 1991:51-58.

-Trevisani F, D'Intino PE, Morselli-Labate AM, Mazzella G, Accogli E, Caraceni P, Domenicali M, De Notariis S, Roda E, Bernardi M. Serum alphafetoprotein for diagnosis of hepatocellular carcinoma in patients with chronic liver disease: influence of HBsAg and anti-HCV status. J Hepatol. 2001 Apr;34(4):570-5. 


\section{دراسة القيمة الإكلينيكية لتقصي مستضدات سرطان الخلية الصدفية

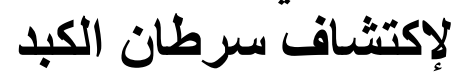

محمد علي عزالعرب1,محمد أحمد حنين2 ,نشوى أحمد عبدالمنعم³ ,محمد حساني², صلاح الدين محمد أحمد , أمين محمد عبد الباقى 2

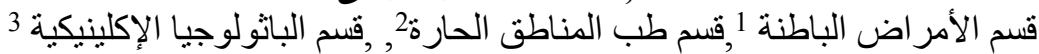

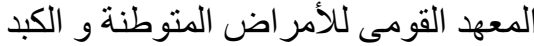
الهيئة العامة للمستشفيات و المعاهد التعليمية الكية

أور ام الكبد السرطانية من الأمر اض الخطبرة التي يصعب علاجها إذا تأخر أكتشافها لذا كانت

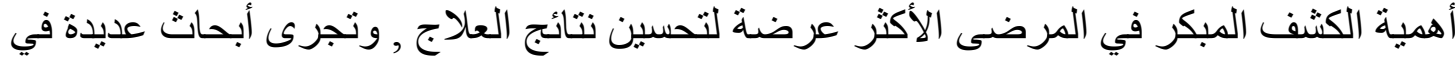

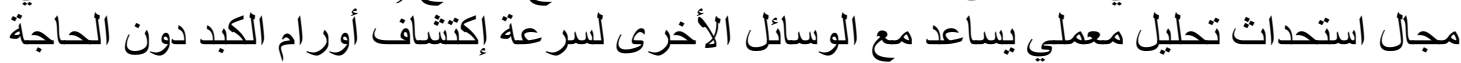
للجوء لعينة الكبد التي قد تسبب إنتشار الورم.

\section{الهوف من اللدراستة}

تقييم مستضدات سرطان الخلية الصدفية كوسيلة مبكرة لإكتشاف سرطان الكبد

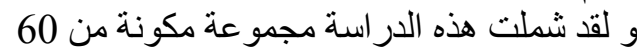

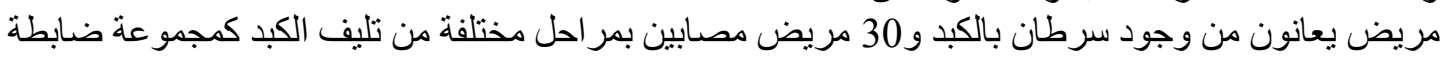
خضعوا للآتي : منانون من

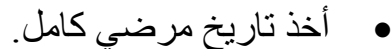

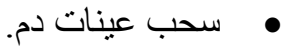

$$
\begin{aligned}
& \text { • عمل وظائف كبد وكلى ودلالات فيروسات كبدية (بي و سي). } \\
& \text { • عل فحص بالموجات فوق الصونية على على البطن. } \\
& \text { • عمل فحص بالأشعة المقطعية الثلاثية المر احل على البطن البطن. } \\
& \text { •عمل تحليل مستضدات سرطان الخلية الصدفية . } \\
& \text { • • • • • }
\end{aligned}
$$

ولقد أظهرت هذه الدراسة وجود مستضدات سرطان الخلبة الصدفية في المرضي المصابين بسرطان الكبد بنسبة

أعلى بكثير عن مرضى المجمو عة الضابطة كما أثتتت الدراسة حساسيته الأعلى عن الألفا فيتوبروتين كوسيلة الإني مبكرة لإكتشاف أورام الكبد.

\section{و لقد أوصت هذه اللدراسة بالأتى:}

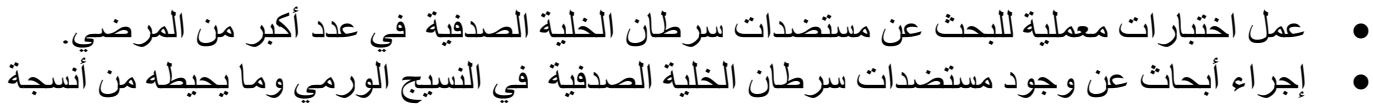

